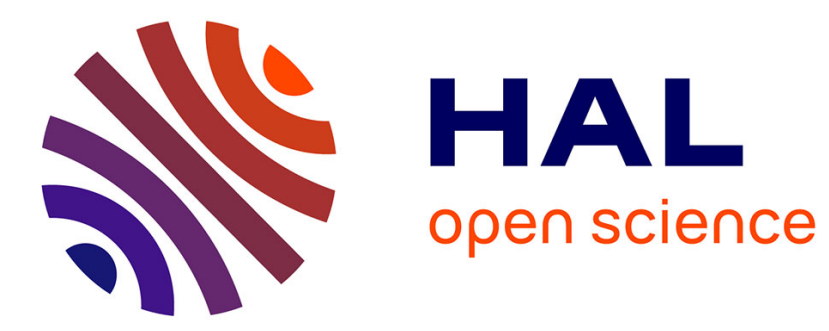

\title{
Carbon footprints and carbon stocks reveal climate-friendly coffee production
}

Henk Rikxoort, Götz Schroth, Peter Läderach, Beatriz Rodríguez-Sánchez

\section{To cite this version:}

Henk Rikxoort, Götz Schroth, Peter Läderach, Beatriz Rodríguez-Sánchez. Carbon footprints and carbon stocks reveal climate-friendly coffee production. Agronomy for Sustainable Development, 2014, 34 (4), pp.887-897. 10.1007/s13593-014-0223-8 . hal-01234838

\section{HAL Id: hal-01234838 \\ https://hal.science/hal-01234838}

Submitted on 27 Nov 2015

HAL is a multi-disciplinary open access archive for the deposit and dissemination of scientific research documents, whether they are published or not. The documents may come from teaching and research institutions in France or abroad, or from public or private research centers.
L'archive ouverte pluridisciplinaire HAL, est destinée au dépôt et à la diffusion de documents scientifiques de niveau recherche, publiés ou non, émanant des établissements d'enseignement et de recherche français ou étrangers, des laboratoires publics ou privés. 


\title{
Carbon footprints and carbon stocks reveal climate-friendly coffee production
}

\author{
Henk van Rikxoort • Götz Schroth • Peter Läderach • \\ Beatriz Rodríguez-Sánchez
}

Accepted: 4 March 2014 / Published online: 26 March 2014

(C) INRA and Springer-Verlag France 2014

\begin{abstract}
Coffee production is impacting the climate by emitting greenhouse gasses. Coffee production is also vulnerable to climate change. As a consequence, the coffee sector is interested in climate-friendly forms of coffee production, but there is no consensus of what exactly this implies. Therefore, we studied two aspects of the climate impact of coffee production: the standing carbon stocks in the production systems and the product carbon footprint, which measures the greenhouse gas emissions per unit weight of coffee produced. We collected data from 116 coffee farms in five Latin American countries, Mexico, Guatemala, Nicaragua, El Salvador, and Colombia, for four coffee production systems: (1) traditional polycultures, (2) commercial polycultures, (3) shaded monocultures, and (4) unshaded monocultures. We found that polycultures have a lower mean carbon footprint, of $6.2-7.3 \mathrm{~kg} \mathrm{CO}_{2}$-equivalent $\mathrm{kg}^{-1}$ of parchment coffee, than monocultures, of $9.0-10.8 \mathrm{~kg}$. We also found that traditional polycultures have much higher carbon stocks in the vegetation, of $42.5 \mathrm{Mg}$ per ha, than unshaded monocultures, of $10.5 \mathrm{Mg}$. We designed a graphic system to classify production systems according to their climate friendliness. We identified several strategies to increase positive and reduce negative climate impacts of coffee production. Strategies include diversification of coffee farms with trees, the use of their wood to substitute for fossil fuel and energy-intensive building materials, the targeted
\end{abstract}

\footnotetext{
H. van Rikxoort

UTZ Certified, Amsterdam, The Netherlands

G. Schroth

Rainforest Alliance, Wageningen, The Netherlands

P. Läderach $(\bowtie)$

International Center for Tropical Agriculture (CIAT), Managua,

Nicaragua

e-mail: p.laderach@cgiar.org

B. Rodríguez-Sánchez

International Center for Tropical Agriculture (CIAT), Cali, Colombia
}

use of fertilizer, and the use of dry or ecological processing methods for coffee instead of the traditional fully washed process.

Keywords Carbon sequestration - Climate change $\cdot$ Coffee agroforestry $\cdot$ Coffee ecosystem conservation $\cdot$ Cool Farm Tool software $\cdot$ Product carbon footprint $\cdot$ System carbon stocks

\section{Introduction}

In many tropical and subtropical regions including Latin America, climate change threatens to become an environmental disaster for farmers, with decreased water availability, new or altered insect and pest pressures, and increased risks of extreme events threatening crop yields and farmer livelihoods (IPCC 2007). Especially in Mesoamerica and the northern Andes, Arabica coffee which is particularly sensitive to climate change (Läderach et al. 2010; Schroth et al. 2009) forms the backbone of thousands of families' livelihoods and contributes significantly to many countries' Gross Domestic Product. However, besides suffering from the effects of climate change, Latin American coffee production has also made its contribution to greenhouse gas emissions from land use change in the recent past. Of the 2.8 million hectares planted to coffee in Mexico, Central America, Colombia, and the Caribbean, 1.1 million hectares had been converted from agroforests to lightly shaded or full sun coffee by the mid-1990s (Perfecto et al. 1997; Rice and Ward 1996). There is, therefore, an increasing need for approaches to coffee farming that not only help farmers adapt to a changing climate but also minimize the contribution of coffee farming itself to global warming.

There are promising signs that the need for climate change mitigation in agricultural supply chains is recognized in the international coffee sector. Some private companies have started estimating the emissions in their coffee supply chain 
by applying life cycle assessment and product carbon footprint methodologies. For example, a life cycle assessment of soluble coffee commissioned by Nestlé indicated that $1 \mathrm{~kg}$ of roasted coffee emitted $35 \mathrm{~kg} \mathrm{CO}_{2}$-equivalent $\left(\mathrm{CO}_{2}\right.$-e) over its entire lifecycle (Humbert et al. 2009). Tchibo (2008) published for one of their products a carbon footprint of $8.4 \mathrm{~kg}$ $\mathrm{CO}_{2}$-e kg ${ }^{-1}$ of roasted coffee, of which $55 \%$ was generated during cultivation and on-farm processing and $30 \%$ during consumption. The remaining $15 \%$ resulted from transport, processing, and waste disposal. This analysis excluded the emissions caused by coffee fermentation and the related generation of waste water. In this regard, an important distinction is between wet processing, in which after de-pulping the coffee beans, the remaining mucilage layers are removed by fermentation and washing with large amounts of water, and dry processing, in which the entire coffee cherries are dried in the sun before the outer layers are removed.

Both Nestlé's and Tchibo's analyses also did not consider potential positive contributions to climate change mitigation from carbon storage in the various types of coffee ecosystems. Since coffee production systems can range from full sun systems to complex agroforests (Moguel and Toledo 1999; Somarriba et al. 2004), the amount of carbon stored in the vegetation can vary widely (Fig. 1). For example, Hergoualc'h et al. (2012) report above- and belowground carbon stocks of 14.1 $\mathrm{Mg} \mathrm{ha}^{-1}$ in an unshaded coffee monoculture versus $32.4 \mathrm{Mg} \mathrm{ha}^{-1}$ in an Inga-shaded monoculture in the Central Valley of Costa Rica. Soto-Pinto et al. (2010) estimate aboveand belowground carbon stocks of $46.3 \mathrm{Mg} \mathrm{ha}^{-1}$ in an Ingashaded system versus $39.4 \mathrm{Mg} \mathrm{ha}^{-1}$ in a system with diversified tree shade. The type of system in which coffee is produced is thus clearly relevant for its overall climate impact.
However, standing carbon stocks are not included in the product carbon footprint which only considers carbon fluxes between the system and its environment (BSI 2008).

The purpose of this study is to assess how different coffee production systems contribute to or mitigate climate change, based on a sample of 116 farms across five Latin American countries. On-farm carbon stocks and carbon footprints of four different coffee production systems as classified by Moguel and Toledo (1999) were assessed. Based on the findings, we propose a paired index approach to characterizing the climate impact of coffee and other tree-crop production systems and present a framework for climate change mitigation in coffee farming.

\section{Materials and methods}

\subsection{Sampling design and data collection}

We collected primary data from 116 individual farms in five countries: Mexico, Guatemala, Nicaragua, El Salvador, and Colombia. The sample sites varied widely in their level of farming intensity, use of inputs, and yields. Following Moguel and Toledo (1999), we classified the systems based on their vegetation, structural complexity, and management into the following four classes: traditional polyculture, commercial polyculture, shaded monoculture, and unshaded monoculture (Table 1).

In all systems, annual input and output data were averaged over the previous five crop cycles, from 2006-2007 until 2010-2011. The data collection took place during 2010-11 which had average climate for the respective regions. Field
Fig. 1 Shaded coffee monoculture in Aguadas, Caldas, located in the heart of Colombia's coffee growing region (the "Coffee Triangle")

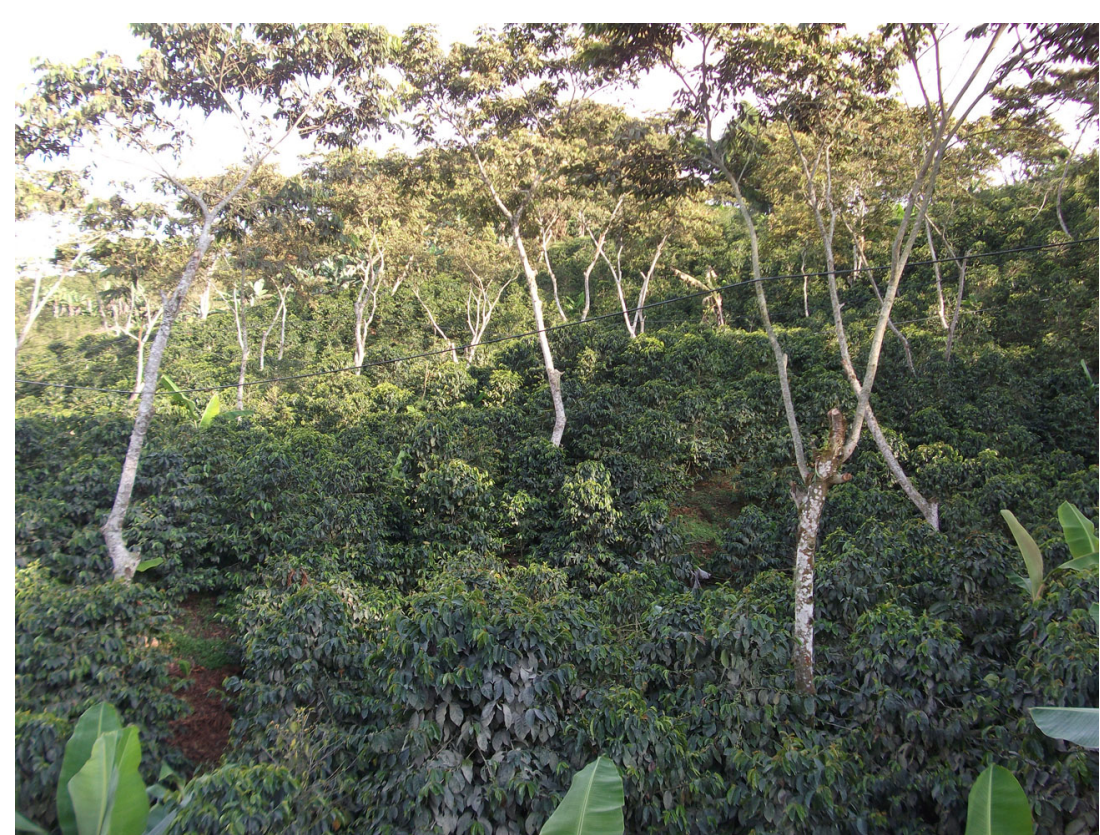


Table 1 Criteria used to classify 116 coffee farms in Mexico, Guatemala, Nicaragua, El Salvador, and Colombia into four system types based on Moguel and Toledo (1999)

\begin{tabular}{llllll} 
System & Number of farms & Shade tree density & Canopy height (m) & Density of co-products & $\begin{array}{l}\text { Input level (plant density, fertilizer, } \\
\text { and pesticide use) and yields }\end{array}$ \\
\hline Traditional polyculture & 29 & Very high & $20-30$ & Medium & Very low \\
Commercial polyculture & 29 & High & $<15$ & High & Low \\
Shaded monoculture & 28 & Medium & $<15$ & Low & Medium \\
Unshaded monoculture & 30 & None & - & None & High \\
\hline
\end{tabular}

data were collected together with local extension workers. Data collection at each individual farm started with a semistructured interview with the farmer to compile data on farm management, fertilizer use, pesticide use, shading, coffee and shade tree densities, yields, processing methodologies, and energy use. Afterward, the coffee plots were visited to verify information gathered in the interview and to measure geographical coordinates. All systems functioned in a polycyclic manner whereby the coffee plots were replanted in small sectors every 5 to 6 years to avoid sudden losses of income when replanting large areas. Plots where the coffee was not yet in production were not included in the survey as the objective of the study was to assess the climate impact of productive coffee systems. Shade tree species and density were obtained from information from the farmer about the number of trees per species on the farm and the farm area and were crosschecked through an inventory of a randomly selected $10 \mathrm{~m} \times$ $10 \mathrm{~m}$ area per farm where tree diameters at breast height $(130 \mathrm{~cm})$ were also measured. Coffee plant spacing, status of the litter layer, weeding practices, canopy height, and the presence of different shade strata were also registered in the field. Approximate values for soil organic matter and soil $\mathrm{pH}$ are needed for the calculation of greenhouse gas emissions from the soil for the carbon footprint analysis. If these data were not available from previous analyses, soil samples were collected and analyzed using the Rapid Soil and Terrain Assessment methodology (Cock et al. 2010).

\subsection{Product carbon footprint calculation}

For calculating the product carbon footprint, we used the Cool Farm Tool (CFT) greenhouse gas calculator (Hillier et al. 2011). This software calculates the annual greenhouse gas emissions in $\mathrm{CO}_{2}$-equivalents $\left(\mathrm{CO}_{2}\right.$-e) considering (1) fertilizer production and $\mathrm{N}_{2} \mathrm{O}$ emissions from fertilizer application based on an empirical model built from over 800 global datasets that refine the Intergovernmental Panel on Climate Change (IPCC) Tier I estimates by factoring in climate, soil texture, soil carbon, and soil $\mathrm{pH}$; (2) pesticide production; (3) fuel and electricity use; (4) methane emissions from waste water that is generated during coffee de-pulping and fermentation; and (5) background soil emissions and the decomposition of prunings and litter on the soil. The IPCC default values used by the software were complemented by literature data and information collected from cooperatives and in the field. The sum of annual litterfall and pruning residues were assumed to be $12 \mathrm{Mg} \mathrm{ha}^{-1}$ for traditional polycultures, $10.5 \mathrm{Mg} \mathrm{ha}^{-1}$ for commercial polycultures, $9 \mathrm{Mg} \mathrm{ha}{ }^{-1}$ for shaded monocultures, and $5 \mathrm{Mg} \mathrm{ha}^{-1}$ for unshaded monocultures based on Beer (1988) and Coltro et al. (2006). Energy use for diesel and electric coffee depulping of $0.11 \mathrm{~kg}^{-1}$ and $0.22 \mathrm{kWh} \mathrm{kg}^{-1}$ parchment coffee, respectively, followed Coltro et al. (2006); water use for fully washed processing (80 $1 \mathrm{~kg}^{-1}$ parchment coffee) followed BIOMAT (1992), and water use for manual de-pulping of $28.81 \mathrm{~kg}^{-1}$ (standard process) and $4.41 \mathrm{~kg}^{-1}$ parchment coffee (ecological process), respectively, was obtained from cooperatives in Guatemala and Nicaragua.

The product carbon footprint was calculated separately for each farm. As the system boundary, we considered the delivery of dried coffee parchment to the dry mill where the coffee is processed into green coffee. Although some of the production systems, especially the commercial polycultures, also yielded products other than coffee, these were not always commercialized or only on local markets, and their economic value compared to the coffee was therefore variable and presumably mostly quite low. Moreover, our objective was to assess the influence of various production systems on the climate impact of coffee farming. To maintain comparable conditions among systems, we allocated all emissions to the coffee as the primary product of all systems, rather than allocating part of the emissions to other (minor) products.

The CFT also permits to compute annual soil carbon sequestration based on an empirical model, but we decided not to include this because the soil carbon dynamics of tree-crop production systems as a function of management practices, soils, and climate are not sufficiently understood. The CFT also allows including annual carbon sequestration in aboveand belowground biomass of coffee and shade trees. Again, we decided not to include this in our product carbon footprint estimates, for the reason that much of this sequestration may not be permanent. In any given tree-crop production system, the biomass in the vegetation may fluctuate cyclically as trees and other plants grow, are harvested, pruned back to avoid 
over-shading of the coffee, or die. Most of the annual biomass increment in the vegetation eventually decomposes, or is burnt on a trash heap, and releases its carbon back into the atmosphere, although some of the wood may be stored for a few years in farm implements of fence posts. That part of the annual wood increment that is burnt replacing fossil fuel, e.g., for domestic heating or cooking, would be a legitimate input into the carbon footprint calculation. ${ }^{1}$ However, the percentage of the annual wood increment on our farms to which this would apply was not measured and was presumably highly variable, including because some common shade trees such as Erythrina spp. and Gliricidia sepium do not produce good fuel wood. Timber harvested from agroforests that is used for long-living products, e.g., furniture or buildings, could also be included in the carbon footprint if the harvesting does not imply a long-term reduction of the standing carbon stocks in the system, that is, if harvested trees are regularly replaced by new growth. Again, only certain hardwood species are suitable for such purposes, and the final use of timber from the farms was not monitored in our study. We therefore conservatively excluded the annual carbon sequestration in the vegetation from the carbon footprint calculation.

\subsection{Calculation of carbon stocks in the vegetation}

Carbon stocks in the vegetation of the coffee production systems were calculated using allometric equations developed by Segura et al. (2006) for coffee bushes and some common shade tree species: Cordia alliodora, Juglans olanchana, Inga tonduzzi, Inga punctata as well as a generic equation for other less frequent shade tree species. For palms and Citrus spp., the allometric equations provided by Pearson et al. (2005) and Schroth et al. (2002), respectively, were used. For all species, a conversion of biomass to carbon of 0.5 was used. Belowground biomass was estimated from aboveground biomass assuming a root/shoot ratio of 0.24 following Somogyi et al. (2008). For coffee bushes, an average diameter of $2.9 \mathrm{~cm}$ (circumference of $9 \mathrm{~cm}$ ) at $15 \mathrm{~cm}$ from ground level was assumed for all systems.

\subsection{Statistical analysis}

Farm data were analyzed by Analysis of Variance followed by Least Significant Difference tests where treatment effects (system types) were significant at $P=0.05$.

\footnotetext{
${ }^{1}$ Only fuel wood replacing fossil fuel outside the coffee system (that is, not including coffee drying for example) would qualify for inclusion in the product carbon footprint to avoid double counting.
}

\section{Results and discussion}

\subsection{Characteristics of production systems}

In line with their definition, the traditional polycultures contained many forest trees including timber species as well as usually some fruit trees (Table 2). Their management was the most extensive among the four system types. The majority of the visited farms used little fertilizer and no pesticides. On average, coffee plant densities were around 4,000 plants per hectare, average coffee yields were with $962 \mathrm{~kg} \mathrm{ha}^{-1}$ significantly lower than in all other system types, and processing was manual. The farmers who used this traditional system were usually smallholders, and El Salvador and Nicaragua were the countries where this system was most commonly found. In the commercial polycultures, which were mostly found in Nicaragua and Guatemala, large forest trees were fewer; instead, the shade cover was made up mostly of nitrogen-fixing legume trees but with a substantial component of fruit trees such as bananas, which distinguished them from shaded monocultures (Table 2). The use of synthetic fertilizers was more common than in traditional polycultures, and pesticides were occasionally used. Average coffee yields of $1,763 \mathrm{~kg} \mathrm{ha}^{-1}$ were almost twice those of traditional polycultures. This was partly due to higher coffee plant densities but mostly to higher inputs and more intensive management. Coffee processing was done manually. Shaded and unshaded monocultures were most common in Colombia where coffee management tends to be more intensive than in the other countries visited. In the shaded monocultures, the shade cover was almost exclusively made up of leguminous trees like Inga spp.; therefore, these farms had no secondary products other than possibly fuel wood. Coffee plant densities were not significantly higher than in commercial polyculture systems, while synthetic fertilizers and pesticides were frequently used. However, average yield levels were with $1,235 \mathrm{~kg} \mathrm{ha}^{-1}$ lower than those in commercial polycultures, suggesting that management intensity, e.g., for pruning and weeding, may often have been lower (Table 2). On the other hand, these farms generally had a better processing infrastructure, including fermentation tanks for the processing of "fully washed" coffee, which in the region is considered the standard method for high quality Arabica coffee. Finally, in the unshaded monocultures, coffee was produced with regular applications of synthetic fertilizers and pesticides. Average coffee plant densities and yields were significantly higher than in the other three system types, and the processing often involved machinery for de-pulping (Table 2).

\subsection{Carbon stocks of coffee production systems}

Average combined carbon stocks in shade trees and coffee plants increased from $10.5 \mathrm{Mg} \mathrm{ha}^{-1}$ in unshaded monocultures 
Table 2 Characteristics, inputs, and outputs of four coffee production systems from five Latin American countries. In addition to trees, banana plants were present in the shade stratum at variable densities in almost all commercial polycultures as well as some traditional polycultures and

\begin{tabular}{|c|c|c|c|c|c|c|c|}
\hline System & $\begin{array}{l}\text { Density of } \\
\text { coffee plants } \\
\left(\mathrm{ha}^{-1}\right)\end{array}$ & $\begin{array}{l}\text { Density of } \\
\text { shade trees } \\
\left(\mathrm{ha}^{-1}\right)\end{array}$ & $\begin{array}{l}\text { Typical coffee } \\
\text { processing } \\
\text { method }\end{array}$ & $\begin{array}{l}\text { Typical use } \\
\text { of fertilizers }\end{array}$ & $\begin{array}{l}\text { Mean } \\
\text { number of } \\
\text { pesticide } \\
\text { applications } \\
\left(\mathrm{yr}^{-1}\right)\end{array}$ & $\begin{array}{l}\text { Mean yield } \\
(\mathrm{kg} \\
\text { parchment } \\
\text { coffee } \\
\left.\mathrm{ha}^{-1} \mathrm{yr}^{-1}\right)\end{array}$ & $\begin{array}{l}\text { Typical } \\
\text { co-products }\end{array}$ \\
\hline $\begin{array}{l}\text { Tradtional } \\
\text { polyculture }\end{array}$ & $\begin{array}{l}3,958 \mathrm{a} \\
\mathrm{SD}=671 \\
(2,288- \\
\quad 5,270)\end{array}$ & $\begin{array}{l}305 \mathrm{a} \\
\mathrm{SD}=83 \\
(140-433)\end{array}$ & $\begin{array}{l}\text { Manual de-pulping. } \\
\text { Ecological } \\
\text { de-pulping } \\
\text { process. Dry } \\
\text { processing } \\
\text { method. }\end{array}$ & $\begin{array}{l}\text { Compost, organic soil, } \\
\text { and foliar amendments, } \\
\text { in some cases } \\
\text { nitrogen, phosphorus, } \\
\text { and potassium. }\end{array}$ & 0 & $\begin{array}{l}962 \mathrm{a} \\
\mathrm{SD}=321 \\
(274-1,477)\end{array}$ & $\begin{array}{l}\text { Fuel wood, } \\
\text { avocado, } \\
\text { mango, } \\
\text { vanilla, } \\
\text { mandarin }\end{array}$ \\
\hline $\begin{array}{l}\text { Commercial } \\
\text { polyculture }\end{array}$ & $\begin{array}{l}4,636 \mathrm{~b} \\
\mathrm{SD}=414 \\
(4,004- \\
5,005)\end{array}$ & $\begin{array}{l}221 \mathrm{~b} \\
\mathrm{SD}=79 \\
(58-347)\end{array}$ & $\begin{array}{l}\text { Manual de-pulping. } \\
\text { Dry processing } \\
\text { method. }\end{array}$ & $\begin{array}{l}\text { Compost, organic soil, } \\
\text { and foliar amendments, } \\
\text { nitrogen, } \\
\text { phosphorus, and } \\
\text { potassium. }\end{array}$ & 0.1 & $\begin{array}{l}1,763 \mathrm{~b} \\
\mathrm{SD}=931 \\
(909-4,600)\end{array}$ & $\begin{array}{l}\text { Fuel wood, } \\
\text { banana, } \\
\text { plantain, } \\
\text { orange, } \\
\text { lemon }\end{array}$ \\
\hline $\begin{array}{l}\text { Shaded } \\
\text { monoculture }\end{array}$ & $\begin{array}{l}5,003 \mathrm{~b} \\
\mathrm{SD}=1,144 \\
(3,000- \\
\quad 8,000)\end{array}$ & $\begin{array}{l}183 \mathrm{~b} \\
\mathrm{SD}=108 \\
(36-423)\end{array}$ & $\begin{array}{l}\text { Manual de-pulping. } \\
\text { Fully washed } \\
\text { processing } \\
\text { method with use } \\
\text { of fermentation } \\
\text { tanks. }\end{array}$ & $\begin{array}{l}\text { Compost, nitrogen, } \\
\text { phosphorus, } \\
\text { potassium, urea, } \\
\text { calcium ammonium } \\
\text { nitrate, limestone, } \\
\text { mono-ammonium, } \\
\text { and di-ammonium } \\
\text { phosphate. Applied in } \\
\text { granulate and foliar } \\
\text { sprays. }\end{array}$ & 0.4 & $\begin{array}{l}1,235 \mathrm{a} \\
\mathrm{SD}=550 \\
(313-2,302)\end{array}$ & Fuel wood \\
\hline $\begin{array}{l}\text { Unshaded } \\
\text { monoculture }\end{array}$ & $\begin{array}{l}6,557 \mathrm{c} \\
\mathrm{SD}=1,279 \\
(4,000- \\
\quad 8,000)\end{array}$ & $\begin{array}{l}0 \\
\mathrm{SD}=0\end{array}$ & $\begin{array}{l}\text { Machine-driven de- } \\
\text { pulping and } \\
\text { mucilage } \\
\text { removing. Fully } \\
\text { washed } \\
\text { processing } \\
\text { method with use } \\
\text { of fermentation } \\
\text { tanks. }\end{array}$ & $\begin{array}{l}\text { Compost, nitrogen, } \\
\text { phosphorus, } \\
\text { potassium, urea, } \\
\text { calcium ammonium } \\
\text { nitrate, and potassium } \\
\text { sulphate. Applied in } \\
\text { granulate } \\
\text { and foliar sprays. }\end{array}$ & 2 & $\begin{array}{l}2,387 \mathrm{c} \\
\mathrm{SD}=1,240 \\
(417-5,175)\end{array}$ & none \\
\hline
\end{tabular}

shaded monocultures. Differences in coffee plant density, shade tree density, and yield among production systems were significant at $P<0.001$. Values in a column followed by the same letter were not significantly different at $P<0.05$ by the Least Significant Difference test

(n)

to $42.5 \mathrm{Mg} \mathrm{ha}^{-1}$ in traditional polycultures, with intermediate values in commercial polycultures $\left(30.2 \mathrm{Mg} \mathrm{ha}^{-1}\right)$ and shaded monocultures (14.3 $\left.\mathrm{Mg} \mathrm{ha}^{-1}\right)$. The differences among systems were highly significant, with exception of the two monoculture systems (Table 3). Traditional polycultures had the highest carbon stocks because their tree stratum contained the highest density of forest trees (Table 2) which were also often of large size. In the commercial polycultures, the shade tree density was lower as many shade trees were smaller legume trees or were replaced by bananas, plantains (Musa spp.), and other fruit trees. In the shaded monocultures, the shade tree density was again lower (Table 2), and the trees (usually Inga spp. or Gliricidia sepium) were regularly pruned to control the shading of the coffee. Finally, in the unshaded monocultures, the carbon stocks were from the coffee plants only whose higher density and carbon stocks could not compensate for the absence of shade trees (Table 3).

\subsection{Product carbon footprints of coffee production systems}

On the average of all production systems, the product carbon footprint was $8.3 \mathrm{~kg} \mathrm{CO}_{2}$-e kg $\mathrm{kg}^{-1}$ of coffee parchment (Table 4). This value is very similar to the one published by Tchibo (2008), despite methodological differences. Our value included greenhouse gas emissions generated by waste water generation during fermentation and de-pulping on the farm or in the cooperative which was not considered by Tchibo (2008), whereas this latter study included international transport, consumption, and disposal of the final coffee product which was beyond the system boundaries as defined in our study. The carbon footprints differed significantly among production systems, with on average lower values for the polyculture systems and higher values for the monocultures (Table 4). The lowest average values were found for the commercial polycultures and the highest values for the shaded 
Table 3 Above- and belowground carbon stocks in shade trees and coffee plants in four different coffee production systems in Mexico, Guatemala, Nicaragua, El Salvador, and Colombia. The differences among systems were significant at $P<0.001$ for all three variables. Values followed by the same letter within a column are not significantly different at $P=0.05$ by the Least Significant Difference test

\begin{tabular}{llll}
\hline Production system & $\begin{array}{l}\text { Carbon stocks in } \\
\text { shade trees } \\
\left(\mathrm{Mg} \mathrm{ha}^{-1}\right)\end{array}$ & $\begin{array}{l}\text { Carbon stocks in } \\
\text { coffee plants } \\
\left(\mathrm{Mg} \mathrm{ha}^{-1}\right)\end{array}$ & $\begin{array}{l}\text { Total system } \\
\text { carbon stocks } \\
\left(\mathrm{Mg} \mathrm{ha}^{-1}\right)\end{array}$ \\
\hline Traditional polyculture & $36.3 \mathrm{a}$ & $6.3 \mathrm{a}$ & $42.5 \mathrm{a}$ \\
& $\mathrm{SD}=13.9$ & $\mathrm{SD}=1.1$ & $\mathrm{SD}=13.7$ \\
& $(16.2-73.0)$ & $(3.7-9.2)$ & $(22.9-78.8)$ \\
Commercial polyculture & $22.7 \mathrm{~b}$ & $7.4 \mathrm{~b}$ & $30.2 \mathrm{~b}$ \\
Shaded monoculture & $\mathrm{SD}=11.9$ & $\mathrm{SD}=0.7$ & $\mathrm{SD}=12.0$ \\
& $(6.2-66.0)$ & $(6.4-8.0)$ & $(13.2-74.1)$ \\
& $6.3 \mathrm{c}$ & $8.0 \mathrm{c}$ & $14.3 \mathrm{c}$ \\
Unshaded monoculture & $\mathrm{SD}=5.2$ & $\mathrm{SD}=1.8$ & $\mathrm{SD}=5.5$ \\
& $(0.8-27.3)$ & $(4.8-12.9)$ & $(5.6-34.6)$ \\
& 0 & $10.5 \mathrm{~d}$ & $10.5 \mathrm{c}$ \\
& & $\mathrm{SD}=2.1$ & $\mathrm{SD}=2.1$ \\
& & $(6.4-12.9)$ & $(6.4-12.9)$
\end{tabular}

monocultures. The carbon footprint of the coffee produced in the polycultures would have further decreased if the commercialization of co-products, such as bananas or other fruits, had been factored in and total emissions had been spread over several products according to their relative economic value. As mentioned before, we did not use product allocation in this study because our objective was to analyze the effect of different production systems on the climate impact of coffee production but also because the commercialization of co-products was variable and in many cases their economic value was presumably quite low compared to that of the coffee. However, where local conditions of market access permit the effective commercialization of co-products, this could further reduce the carbon footprint of coffee produced in polyculture systems.

On the average of all systems, $35 \%$ of the carbon footprint of the coffee was due to fertilizer production and application including background soil emissions, $7 \%$ was due to emissions from prunings and crop residues decomposing on the ground, and $57 \%$ was due to emissions from fermentation and waste water. These three components explained by far the largest part of the total carbon footprint. The contribution of energy and fuel use for transport and on-farm processing was on average less than $2 \%$ of the carbon footprint (Table 4 ), and
Table 4 Average, standard deviation (SD), and range (in brackets) of the carbon footprint of coffee produced in four production systems in five Latin American countries. All values are in $\mathrm{kg} \mathrm{CO}_{2}$-equivalent $\mathrm{kg}^{-1}$ parchment coffee. Values in a column followed by the same letter are not significantly different at $P=0.05$

\begin{tabular}{|c|c|c|c|c|c|}
\hline System type & $\begin{array}{l}\text { Emissions from soils and } \\
\text { fertilizer production and } \\
\text { application }\end{array}$ & $\begin{array}{l}\text { Emissions from crop } \\
\text { residue management }\end{array}$ & $\begin{array}{l}\text { Emissions from electricity, } \\
\text { fuel and gas use, } \\
\text { and transport }\end{array}$ & $\begin{array}{l}\text { Emissions from } \\
\text { fermentation and } \\
\text { waste water production }\end{array}$ & All sources \\
\hline $\begin{array}{l}\text { Traditional polyculture } \\
\quad(n=29)\end{array}$ & $\begin{array}{l}3.5 \\
\mathrm{SD}=2.3 \\
(1.5-10.6)\end{array}$ & $\begin{array}{l}1.3 \mathrm{a} \\
\mathrm{SD}=0.8 \\
(0.7-3.8)\end{array}$ & $\begin{array}{l}0.16 \mathrm{ab} \\
\mathrm{SD}=0.05 \\
(0.10-0.20)\end{array}$ & $\begin{array}{l}2.4 \mathrm{a} \\
\mathrm{SD}=1.7 \\
(0.6-4.1)\end{array}$ & $\begin{array}{l}7.3 \mathrm{ab} \\
\mathrm{SD}=4.2 \\
(3.3-18.6)\end{array}$ \\
\hline $\begin{array}{l}\text { Commercial polyculture } \\
\quad(n=29)\end{array}$ & $\begin{array}{l}2.4 \\
\mathrm{SD}=1.2 \\
(0.7-6.5)\end{array}$ & $\begin{array}{l}0.6 \mathrm{~b} \\
\mathrm{SD}=0.3 \\
(0.1-1.0)\end{array}$ & $\begin{array}{l}0.21 \mathrm{a} \\
\mathrm{SD}=0.12 \\
(0.00-0.40)\end{array}$ & $\begin{array}{l}3.0 \mathrm{a} \\
\mathrm{SD}=2.1 \\
(0.6-7.7)\end{array}$ & $\begin{array}{l}6.2 \mathrm{a} \\
\mathrm{SD}=2.2 \\
(4.1-11.7)\end{array}$ \\
\hline $\begin{array}{l}\text { Shaded monoculture } \\
\quad(n=28)\end{array}$ & $\begin{array}{l}3.2 \\
\mathrm{SD}=2.2 \\
(0.7-10.9)\end{array}$ & $\begin{array}{l}0.5 \mathrm{~b} \\
\mathrm{SD}=0.3 \\
(0.2-1.2)\end{array}$ & $\begin{array}{l}0.11 \mathrm{~b} \\
\mathrm{SD}=0.25 \\
(0.00-1.10)\end{array}$ & $\begin{array}{l}7.1 \mathrm{~b} \\
\mathrm{SD}=2.4 \\
(0.6-11.3)\end{array}$ & $\begin{array}{l}10.8 \mathrm{c} \\
\mathrm{SD}=3.7 \\
(4.0-18.8)\end{array}$ \\
\hline $\begin{array}{l}\text { Unshaded monoculture } \\
\qquad(n=30)\end{array}$ & $\begin{array}{l}2.7 \\
\mathrm{SD}=1.8 \\
(0.7-7.3)\end{array}$ & $\begin{array}{l}0.2 \mathrm{c} \\
\mathrm{SD}=0.1 \\
(0.0-0.5)\end{array}$ & $\begin{array}{l}0.10 \mathrm{~b} \\
\mathrm{SD}=0.11 \\
(0.00-0.30)\end{array}$ & $\begin{array}{l}6.1 \mathrm{~b} \\
\mathrm{SD}=1.8 \\
(4.0-7.7)\end{array}$ & $\begin{array}{l}9.0 \mathrm{bc} \\
\mathrm{SD}=2.9 \\
(5.2-15.5)\end{array}$ \\
\hline All farms $(n=116)$ & $\begin{array}{l}2.9 \\
\mathrm{SD}=2.0 \\
(0.7-10.9)\end{array}$ & $\begin{array}{l}0.6 \\
\mathrm{SD}=0.6 \\
(0.0-3.8)\end{array}$ & $\begin{array}{l}0.14 \\
\mathrm{SD}=0.16 \\
(0.00-1.10)\end{array}$ & $\begin{array}{l}4.7 \\
\mathrm{SD}=2.8 \\
(0.6-11.3)\end{array}$ & $\begin{array}{l}8.3 \\
\mathrm{SD}=3.7 \\
(3.3-18.8)\end{array}$ \\
\hline Level of significance $(P)$ & 0.101 & $<0.001$ & 0.030 & $<0.001$ & $<0.001$ \\
\hline
\end{tabular}


the contribution of pesticide applications was negligible (data not shown). Since both of these components are somewhat cumbersome to determine, it may be possible to omit them from certain routine determinations once their relatively small contribution to the total carbon footprint has been established in preliminary evaluations. A notable characteristic of all components of the carbon footprint of all systems was their high variability among farms even within the same system type (Table 4). This reflected widely differing practices within each system type, such as water use in the fermentation and de-pulping process, but also the efficiency with which some inputs were applied.

The carbon footprint from soils and fertilizer use did not differ significantly among systems, reflecting the high variability of these emissions in all systems and the fact that in the more intensively managed farms the higher use of mineral fertilizer was often compensated by higher yields (Table 2). Considering individual farms, there was an overall negative relationship between the soil and fertilizer related carbon footprint and yield (Fig. 1). Some traditional polycultures had among the highest soil and fertilizer-related carbon footprint of all farms. This was because at their very low yield levels, background soil emissions accrued to a small amount of product and even modest applications of mineral or organic fertilizer could drive the carbon footprint further up if they did not result in proportional yield increases. At higher yield levels, many shaded and unshaded monoculture systems, but also some commercial polycultures, had carbon footprint values above the average. This indicated inefficient use of fertilizer, presumably because other growth factors such as water or overall management of the plantation including weeding, pruning, and replanting of the coffee bushes were yield limiting. The highest-yielding farms had generally a low soil and fertilizer-related carbon footprint, reflecting the accrual of background soil emissions to a large amount of product and the efficient use of fertilizer (Fig. 1). For these farms, the soil and fertilizer-related carbon footprint tended toward a value of about $1 \mathrm{~kg} \mathrm{CO}_{2}-\mathrm{e} \mathrm{kg}^{-1}$ parchment coffee, while values above about $4 \mathrm{~kg} \mathrm{CO}_{2}-\mathrm{e} \mathrm{kg}^{-1}$ parchment coffee would generally indicate high background emissions and/or inefficient fertilizer use. The large variability of the soil and fertilizer-related carbon footprint at low to medium yield levels suggests that more efficient use of external inputs could make a significant contribution to reducing the final carbon footprint of many farms.

The emissions from decomposing litter and prunings were higher in the shaded systems, and especially in the traditional polycultures with their heavy tree canopies, than in the unshaded monocultures which generated much lower amounts of organic residues (Table 4). Inclusion of soil carbon sequestration would have likely changed this result since more litter production would be expected to lead over time to higher soil organic matter contents. However, we felt that there are not yet enough quantitative studies in tree-crop systems to include soil carbon sequestration in our carbon footprint calculations. This is an important field for research.

A major difference between the polycultures on the one hand and the more technified monoculture systems on the other was in the generation of waste water from fermentation and de-pulping, and the resultant emission of greenhouse gases, especially methane (Table 4). By mostly using the fully washed coffee processing with large fermentation tanks and washing channels, the shaded and unshaded monoculture farms used much larger volumes of water per kilogram of coffee than the polyculture farms and cooperatives that usually did not have the infrastructure for fully washed processing and mostly used dry processing of the coffee (Table 2). On the average, the carbon footprint due to fermentation and waste water was a little over twice as high on the monoculture farms than on the polyculture farms, with a highly significant difference between those two classes of systems (Table 4). Since emissions from waste water contributed more than half of the total carbon footprint, the higher waste water generation on the more technified monoculture farms resulted in an overall carbon footprint that was about $46 \%$ higher in the monoculture than in the polyculture systems (Table 4).

\subsection{How to produce climate-friendly coffee?}

We have presented two ways on how coffee production systems could differ in their (positive or negative) contribution to climate change. One is the amount of carbon that is stored in their vegetation (and the soil, if it is included in the analysis), and the other is the amount of greenhouse gases that are released for every unit of coffee produced, that is, the product carbon footprint. These are two separate and, as we have seen, largely independent measures of climate impact. The climate benefits of high standing carbon stocks in a land use system are not captured in the carbon footprint which measures carbon flows between the production system and its environment. Everything else being equal, the carbon footprint of a kilogram of coffee will not be different if it has been grown in a system with high or low standing carbon stocks. Similarly, the carbon stock of a system is not affected by the carbon footprint, and traditional polyculture farms with high carbon stocks in their tree biomass can have very high carbon footprint values if background soil emissions are high or if fertilizer is applied inefficiently and fails to increase yields that are kept at a low level by other limiting factors. These may include over-shading, an old population of coffee plants, insufficient weeding or coffee pruning, or insufficient rainfall. Ideally, these two climate-related characteristics of tree-crop production systems would be integrated into a single index of climate impact, but this is not easily resolved due to the difference in concept and units of measurement between a flux rate (the carbon footprint) and a stock. 
We therefore use here a different approach that treats carbon footprint and carbon stock as two interrelated dimensions of climate impact that both need to be optimized in order to produce more climate-friendly coffee. The approach is illustrated in Fig. 3, which divides the 116 farms of this study into four groups: those with a carbon footprint below the median and a carbon stock above the median of all farms (Quadrant A) - the most desirable combination from a climate mitigation point of view; those with a carbon footprint above the median and carbon stock below the median of all farms (Quadrant D) - the least desirable combination from a climate mitigation point of view; and the two groups with intermediate combinations of carbon footprint and carbon stock (Quadrants B and C). The system averages of the traditional and commercial polyculture systems were located in Quadrant A, but this was far from true for all farms in these two groups, some of which had very high carbon footprint values, as discussed previously. A climatefriendly management objective for these farms would thus be to reduce the carbon footprint below the median value to move into Quadrant A. The system averages of the shaded and unshaded monocultures, on the other hand, were both located in Quadrant D, but again this was not the case with all individual farms. Some shaded monocultures were located in Quadrants B or C, although there were none in Quadrant A. Through a reduction of the carbon footprint, e.g., by changing the post-harvest practices and more targeted fertilizer use, the farms in Quadrant B might be able to move into Quadrant A, while those farms currently in Quadrant $\mathrm{C}$ might be able to increase their system carbon stocks without negatively affecting coffee yields, although this would have to be looked at on a case-by-case basis. For the unshaded monocultures, Quadrants A and B were unattainable because their carbon stocks were essentially by definition below the median, while a number of farms were in Quadrant $\mathrm{C}$ based on their relatively favorable carbon footprint (Fig. 3).

We now discuss strategies to make coffee production climate friendlier by reducing negative and increasing positive climate impacts of coffee production and processing, essentially to move farms into Quadrant A of Fig. 3.

\subsubsection{Include trees in coffee production systems}

The diversification of coffee production systems with trees can contribute to climate change mitigation in several ways. The most obvious is to increase system carbon storage where the farms in our sample ranged from little over 6 to almost $80 \mathrm{Mg} \mathrm{ha}^{-1}$ (Table 3). However, besides increasing system carbon storage, trees can also contribute to reducing the carbon footprint of agroforestry products such as coffee. Shade trees with reasonably dense wood such as Inga spp. could contribute to reducing the carbon footprint of coffee production if their wood is used as a substitute for fossil fuel, e.g., kerosene, in domestic heating or cooking. The same is true for timber trees if their wood is used for long-living products such as buildings, especially if they replace more energy-intensive materials and are also burnt substituting for fossil fuel at the end of their life cycle. If the final use for energy generation substituting for fossil fuel is ensured, the inclusion of wood harvested from coffee production systems in the carbon footprint of their commercial products is legitimate and would reduce their carbon footprint compared to that of monoculture systems. However, monitoring the final use of wood from agroforestry systems is not easy, and the question whether wood production should be included in routine carbon footprint calculations is thus in part a logistic one.

Softwood species such as Erythrina spp. or Gliricidia sepium, on the other hand, whose biomass has little or no use value and is generally left to decompose in the field, do not have this direct effect on the carbon footprint, although they could reduce nitrogen fertilizer needs through their nitrogen fixation and production of nitrogen-rich litter and prunings (Nygren et al. 2012). Nitrogen-rich residues from shade trees can also increase $\mathrm{N}_{2} \mathrm{O}$ emissions as they decompose on the ground, thereby increasing the carbon footprint (Hergoualc'h et al. 2012). However, since greenhouse gas emissions from organic residues are generally much smaller than those from soils and fertilizer (Table 4), as long as nitrogen-fixing trees help to significantly reduce the need for nitrogen fertilizers, their overall effect on the carbon footprint should usually be positive, although this requires further research. Added to this would be the beneficial effects of shade trees on soil organic matter buildup, although this effect has not been included in our carbon footprint calculations for lack of sufficient quantitative studies in coffee production systems.

Although less efficient in terms of carbon storage than forest trees and usually not nitrogen fixing, fruit trees can also indirectly contribute to lowering the carbon footprint if their products are commercialized and product allocation is used in assigning the total greenhouse gas emissions from a production system to its various products relative to their economic value. For example, bananas and plantains that are often used for shading coffee store little carbon but do increase the range of outputs from a land use system besides contributing to household food security. The same is true for tree crops such as citrus and avocados that are common components of Central American coffee agroforestry systems, and of course for timber trees if their timber is sold and the trees are being continuously replaced in a polycyclic management system. Diversified production systems also tend to reduce the vulnerability of farming 
systems to climate change as well as other environmental and market shocks and have therefore recently received increasing attention among farmers and policy makers (Ruf and Schroth 2013; Schroth and Ruf 2014).

\subsubsection{Reduce emissions from fertilizer production and application}

Together with background soil emissions, fertilizer production and application contributed $35 \%$ on average to the carbon footprint but with large variations among systems and individual farms (Fig. 1). The efficient use of fertilizers is therefore an important component of climate-friendly coffee production systems. Our data suggest that fertilizers were often wasted on the farms of our sample because they were applied to systems whose productivity was limited by other factors, such as light, water, or the age and state of the coffee plants. A large impact on the carbon footprint comes especially from nitrogen fertilizers, which are energy intensive to produce, cause $\mathrm{N}_{2} \mathrm{O}$ emissions from soils upon their application, and are easily leached even in tree-dominated systems if they are not quickly taken up by the plants (Babbar and Zak 1995; Schroth et al. 1999, 2000). Fertilizers should therefore be applied in accordance with recommendations from the local extension services, based on regular soil and foliar analyses. The soil and fertilizer-related carbon footprint should be monitored, keeping in mind that the most efficient farms in this regard operate at or below a soil and fertilizer-related carbon footprint of $1 \mathrm{~kg} \mathrm{CO}_{2}$-e kg${ }^{-1}$ parchment coffee (Fig. 2).

\subsubsection{Reduce emissions from fermentation and waste water production}

Post-harvesting practices contributed on average with over $50 \%$ to the carbon footprint of coffee production. They can also cause significant water pollution if waste water is directly released into natural water courses, although this practice is now prohibited throughout the region. In a traditional fully wet processing method, where coffee parchment ferments in tanks for 12 to $36 \mathrm{~h}$, significant methane emissions are caused by the anaerobic decomposition of the mucilage. This is followed by artificial drying of the coffee that causes some additional greenhouse gas emissions if fossil fuels or energy from the grid are used, although energy use was a much smaller emission source than waste water in our study (Table 4). In comparison, dry processing reduces especially emissions from the fermentation process but also from energy and fossil fuel use. Unfortunately, wet processing is still considered the standard for the production of high-quality coffee in Latin America. A possible solution for high-end markets could be to use one of several available fermentation methods that reduce drastically the amounts of waste water produced (Cadena and Baker 2001). Awareness building among coffee buyers for this important source of greenhouse gas emissions is also needed, based on the argument that the production of coffee with a low-carbon footprint is virtually impossible if traditional wet processing methods are used. Another option for larger production units would be to capture the methane for use as cooking gas, or to run biogas generators that can be used for de-pulping
Fig. 2 Relationship between soil and fertilizer-related carbon footprint and yield level of parchment coffee produced in four production systems in five Latin American countries. The small letters show individual farms, while the large letters show means and standard deviations per system. The regression equation (dashed line) is Product Carbon Footprint $=$ $2,253 *$ yield $-1.0279+1 . T P$ traditional polyculture, $C P$ commercial polyculture, $S M$ shaded monoculture, $U M$ unshaded monoculture

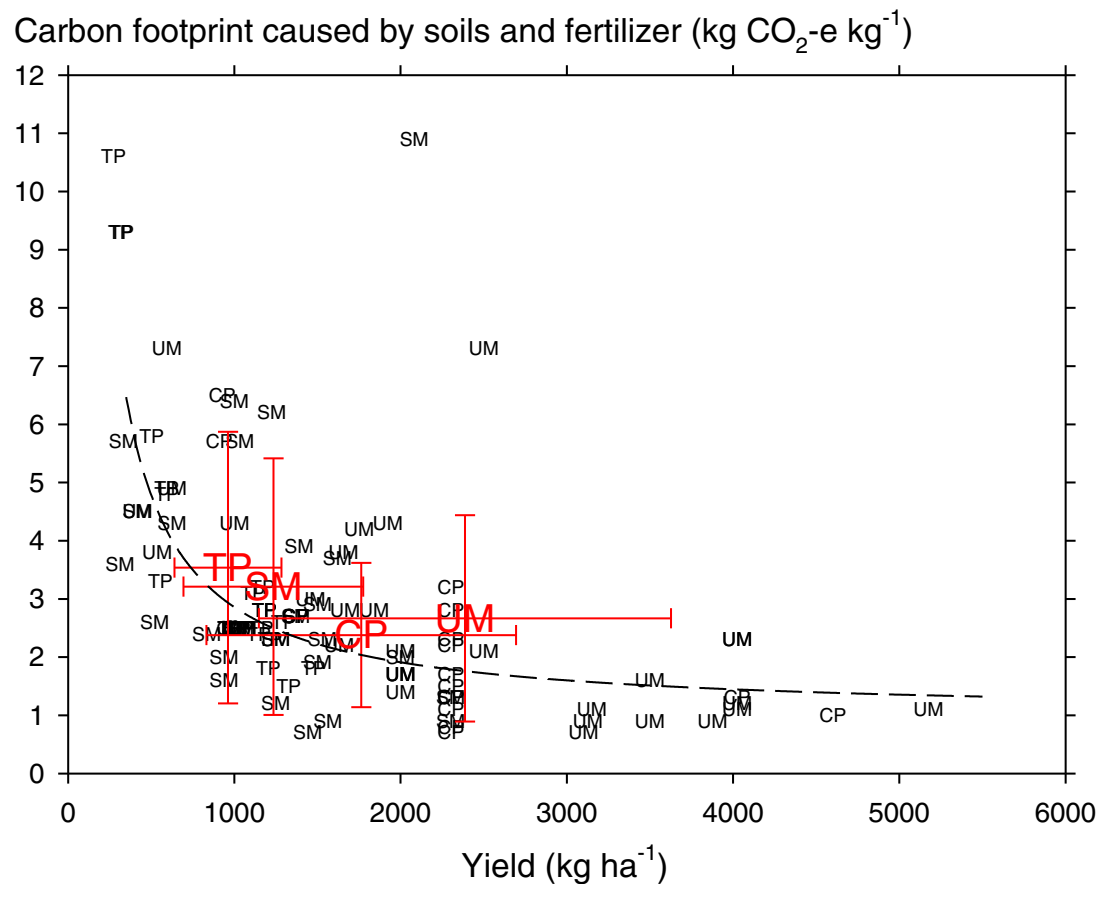


Fig. 3 Relationship between the carbon footprint of parchment coffee and carbon stocks in the vegetation for 116 coffee farms in four countries of Latin America, showing a greater average climate friendliness of polyculture than monoculture systems. The small letters show individual farms, while the large letters show means and standard deviations per system. The dashed lines show the median of carbon footprints and carbon stocks, respectively, dividing the field into four quadrants of most desirable $(A)$, least desirable $(D)$, and intermediate $(B, C)$ climate impact. $T P$ traditional polyculture, $C P$ commercial polyculture, $S M$ shaded monoculture, $U M$ unshaded monoculture

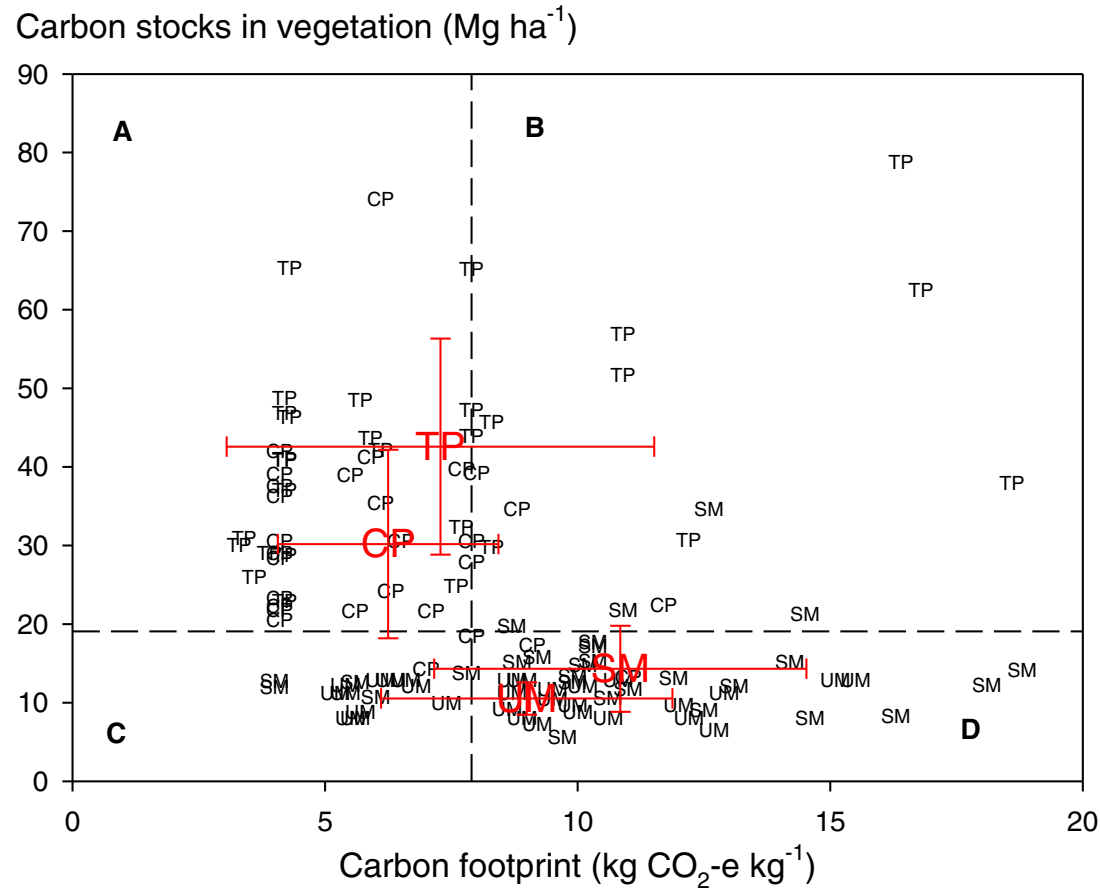

machinery and pumps in the wet mill (Rodríguez and Zambrano 2010; UTZ Certified 2013).

\section{Conclusions}

This study showed that coffee production systems differ widely in their contribution to climate change both through variable carbon storage in the vegetation and large differences in their product carbon footprint. Especially traditional polycultures can play an important role in maintaining high carbon stocks in their vegetation. Since shading limits the attainable coffee yields, it is important to limit the amounts of inputs such as mineral and organic fertilizers to avoid overfertilization, which drives up the carbon footprint. These systems are particularly advantageous where low management costs rather than high coffee yields are important management objectives, as well as for inhabited protected areas (Cortina-Villar et al. 2012; Schroth et al. 2011). Carbon stocks in the vegetation of commercial polycultures are usually lower than in traditional polycultures but can be substantial. These systems may often be among the most promising ways of producing coffee with a low-carbon footprint while also reducing the vulnerability of coffee farmers to climate and market risks through diversification (Ruf and Schroth 2013; Schroth and Ruf 2014). Shaded and unshaded monoculture systems had higher values for the carbon footprint in this study, but it should be kept in mind that these were often due to higher greenhouse gas emissions during the postharvest processing of the coffee rather than the production process itself (Table 4). Our data suggest that it may not be impossible to produce low-carbon footprint coffee in intensive production systems but that the most efficient production system cannot compensate for high emissions during wet processing. However, the unshaded monoculture systems had by definition low-carbon stocks in the vegetation, and even of the shaded monoculture farms none made it into the "holy grail" of climate-friendly coffee (see Quadrant A, Fig. 3).

Mitigation strategies in Latin American coffee production should focus on: (1) conserving on-farm carbon stocks in the biomass which also implies avoiding on- and off-farm deforestation, using harvested wood for replacement of fossil fuels or for long-living products such as building materials, and diversifying production systems with a range of tree species; (2) reducing emissions from fertilizer production, transport, and application, and especially to use fertilizers efficiently and in accordance with expert recommendations; and (3) reducing the emissions from the generation and discharge of waste water through preferential use of dry-processing or improved wet-processing methods.

We suggest that the two dimensions of climate impact of coffee production systems - long-term carbon storage and annual carbon fluxes (the product carbon footprint) - are best captured in a paired index of climate friendliness, as illustrated graphically in Fig. 3. Such a graphic index where individual or groups of coffee farms can be benchmarked relative to a reference group, such as their cooperative, a country or region, or the suppliers of a trader or product, could serve as a flexible guide toward more climate-friendly coffee production and sourcing practices. 
Acknowledgments This study was conducted under the CGIAR research program on Climate Change, Agriculture and Food Security (CCAFS). The fieldwork was carried out as a part of the Coffee Under Pressure (CUP) project funded by Green Mountain Coffee Roasters. We thank the coffee farmers and the staff from the organizations Apecafe, Acoderol, Prodecoop, Pronatura Sur, ECOM, and Neumann for their collaboration in the field data collection, as well as Jonathan Hillier, Jos van Hal, Stephanie Daniels, Diana Sophia Blackburn Cuero, and Katharina Plassmann for their advice during this study.

\section{References}

Babbar LI, Zak DR (1995) Nitrogen loss from coffee agroecosystems in Costa Rica: leaching and denitrification in the presence and absence of shade trees. J Environ Qual 24:227-233. doi:10.2134/jeq1995. $00472425002400020003 x$

Beer J (1988) Litter production and nutrient cycling in coffee (Coffea arabica) or cacao (Theobroma cacao) plantations with shade trees. Agrofor Syst 7:103-114. doi:10.1007/BF00046846

BIOMAT (1992) Estudio y Diseño de la Planta de Tratamiento de los Desechos del Café en la Finca "San Luis". Alcaldia de Matagalpa y Oficina Biogás y Saneamiento Ambiental, Matagalpa, Nicaragua

BSI (2008) Publicly Available Specification (PAS) 2050: Specification for the assessment of the life cycle greenhouse gas emissions of goods and services. British Standards Institution, London

Cadena G, Baker PS (2001) Sustainable coffee. In: Baker PS (ed) Coffee futures: A source book of some critical issues confronting the coffee industry. CABI-FEDERACAFE-USDA-ICO, Chinchina, pp 56-65

Cock JH, Álvarez DM, Estrada M (2010) Rapid soil and terrain assessment. Centro International de Agricultura Tropical (CIAT), Cali

Coltro L, Mourad A, Oliveira P, Baddini J, Kletecke R (2006) Environmental profile of Brazilian green coffee. Int J Life Cycle Assess 11:16-21. doi:10.1065/lca2006.01.230

Cortina-Villar S, Plascencia-Vargas H, Vaca R, Schroth G, Zepeda Y, Soto-Pinto L, Nahed-Toral J (2012) Resolving the conflict between ecosystem protection and land use in protected areas of the Sierra Madre de Chiapas, Mexico. Environ Manage 49:649-662. doi:10. 1007/s00267-011-9799-9

Hergoualc'h K, Blanchart E, Skiba U, Hénault C, Harmand J-M (2012) Changes in carbon stock and greenhouse gas balance in a coffee (Coffea arabica) monoculture versus an agroforestry system with Inga densiflora, in Costa Rica. Agric Ecosyst Environ 148:102-110. doi:10.1016/j.agee.2011.11.018

Hillier J, Walter C, Malin D, Garcia-Suarez T, Mila-i-Canals L, Smith P (2011) A farm-focused calculator for emissions from crop and livestock production. Environ Model Software 26:1070-1078. doi: 10.1016/j.envsoft.2011.03.014

Humbert S, Loerincik Y, Rossi V, Margni M, Jolliet O (2009) Life cycle assessment of spray dried soluble coffee and comparison with alternatives (drip filter and capsule espresso). J Clean Prod 17: 1351-1358. doi:10.1016/j.jclepro.2009.04.011

IPCC (2007) Climate Change 2007: Impacts, adaptation and vulnerability. Cambridge University Press, Cambridge

Läderach P, Haggar JP, Lau C, Eitzinger A, Ovalle-Rivera O, Baca M, Jarvis A, Lundy M (2010) Mesoamerican coffee: Building a climate change adaptation strategy. CIAT Policy Brief No. 2. Centro Internacional de Agricultura Tropical, Cali

Moguel P, Toledo VM (1999) Biodiversity conservation in traditional coffee systems of Mexico. Conserv Biol 13:11-21. doi:10.1046/j. 1523-1739.1999.97153.x

Nygren P, Fernández MP, Harmand J-M, Leblanc HA (2012) Symbiotic dinitrogen fixation by trees: an underestimated resource in agroforestry systems? Nutr Cycl Agroecosyst 94:123-160. doi:10. 1007/s10705-012-9542-9

Pearson T, Walker S, Brown S (2005) Source book for LULUCF projects. Winrock International, Arlington

Perfecto I, Vandermeer J, Hanson P, Cartín V (1997) Arthropod biodiversity loss and the transformation of a tropical agro-ecosystem. Biodivers Conserv 6:935-945. doi:10.1023/A:1018359429106

Rice RA, Ward JR (1996) Coffee, conservation, and commerce in the western hemisphere. Smithsonian MIgratory Bird Center and National Resources Defence Council, Washington DC

Rodríguez N, Zambrano DA (2010) Los subproductos del café: fuente de energía renovable. Av Técnicos Cenicafé 393:1-8

Ruf F, Schroth G (2013) Cultures Pérennes Tropicales: Enjeux Économiques et Écologiques de la Diversification. Editions Quae, Montpellier

Schroth G, Ruf F (2014) Farmer strategies for tree crop diversification in the humid tropics. A review. Agron Sustain Dev. doi:10.1007/ s13593-013-0175-4

Schroth G, da Silva LF, Seixas R, Teixeira WG, Macêdo JLV, Zech W (1999) Subsoil accumulation of mineral nitrogen under polyculture and monoculture plantations, fallow and primary forest in a ferralitic Amazonian upland soil. Agric Ecosyst Environ 75:109-120. doi:10. 1016/S0167-8809(99)00068-7

Schroth G, Rodrigues MRL, D'Angelo SA (2000) Spatial patterns of nitrogen mineralization, fertilizer distribution and roots explain nitrate leaching from mature Amazonian oil palm plantation. Soil Use Manag 16:222-229. doi:10.1111/j.1475-2743.2000.tb00197.x

Schroth G, D'Angelo SA, Teixeira WG, Haag D, Lieberei R (2002) Conversion of secondary forest into agroforestry and monoculture plantations in Amazonia: consequences for biomass, litter and soil carbon stocks after seven years. For Ecol Manage 163:131-150. doi: 10.1016/S0378-1127(01)00537-0

Schroth G, Läderach P, Dempewolf J, Philpott SM, Haggar JP, Eakin H, Castillejos T, Garcia-Moreno J, Soto-Pinto L, Hernandez R, Eitzinger A, Ramirez-Villegas J (2009) Towards a climate change adaptation strategy for coffee communities and ecosystems in the Sierra Madre de Chiapas, Mexico. Mitig Adapt Strateg Glob Chang 14:605-625. doi:10.1007/s11027-009-9186-5

Schroth G, da Mota MSS, Hills T, Soto-Pinto L, Wijayanto I, Arief CW, Zepeda Y (2011) Linking carbon, biodiversity and livelihoods near forest margins: The role of agroforestry. In: Kumar BM, Nair PKR (eds) Carbon sequestration in agroforestry: Processes, policy, and prospects. Springer, Berlin, pp 179-200. doi:10.1007/978-94-0071630-8 10

Segura M, Kanninen M, Suárez D (2006) Allometric models for estimating aboveground biomass of shade trees and coffee bushes grown together. Agrofor Syst 68:143-150. doi:10.1007/s10457-006-9005-x

Somarriba E, Harvey CA, Samper M, Anthony F, González J, Staver C, Rice RA (2004) Biodiversity conservation in neotropical coffee (Coffea arabica) plantations. In: Schroth G, Fonseca GAB, Harvey CA, Gascon C, Vasconcelos HL, Izac A-MN (eds) Agroforestry and biodiversity conservation in tropical landscapes. Island Press, Washington, DC, pp 198-226

Somogyi Z, Teobaldelli M, Federici S, Matteucci G, Pgaliari V, Grassi G, Seufert G (2008) Allometric biomass and carbon factors database. iForest - Biogeosci For 1:107-113. doi:10.3832/ifor0463-0010107

Soto-Pinto L, Anzueto M, Mendoza J, Ferrer GJ, de Jong B (2010) Carbon sequestration through agroforestry in indigenous communities of Chiapas, Mexico. Agrofor Syst 78:39-51. doi:10.1007/ s10457-009-9247-5

Tchibo (2008) Case Study Tchibo Privat Kaffee Rarity Machare. PCF Pilot Project Germany. Öko-Institut e.V, Berlin

UTZ Certified (2013) Energy from coffee waste in Central America. Pilot Project Central America. UTZ Certified, Amsterdam, Availabe from: https://www.utzcertified.org/nl/aboututzcertified/fielddevelopment $/ 2373$ 